\title{
A comparison of the survivorship and growth of shallow-water gorgonian species of Puerto Rico
}

\author{
Paul M. Yoshioka, Beverly Buchanan Yoshioka \\ Department of Marine Sciences, University of Puerto Rico, Mayaguez, Puerto Rico 00709, USA
}

\begin{abstract}
Survival and growth of shallow-water gorgonian colonies were monitored from early winter 1983 to late spring 1988 at 2 exposed sites on the southwest coast of Puerto Rico. Survival rates were about $92 \% \mathrm{yr}^{-1}$ at both sites, relatively constant during the study period, and not significantly different among species. The major sources of mortality were detachment, fracture of the axial skeleton near the colony base, and competitive overgrowth. Sources of mortality differed significantly between sites but apparently not among species. Growth rates (increases in colony height) averaged about $2.0 \mathrm{~cm} \mathrm{yr}^{-1}$ for most species and ranged from 0.8 to $4.5 \mathrm{~cm} \mathrm{yr}^{-1}$ among species. All species displayed high intraspecific variations in growth. Results emphasize the similarities, rather than differences, in the growth and survival of shallow-water gorgonian species.
\end{abstract}

\section{INTRODUCTION}

The organization of coral reef communities is undoubtedly related to the extent to which species differ ecologically (e.g. Connell 1978). In this report we examine the survival and growth of shallow-water gorgonian colonies in Puerto Rico as a preliminary assessment of species-specific patterns in this community. Previous studies on colony survival and growth rates for gorgonians in the Caribbean have been conducted by Cary (1914), Kinzie (1974), and Yoshioka (1979), among others. In general these studies indicate that colonies experience relatively low mortalities and high variability in growth rates. For instance, $>95 \%$ of the Gorgonia ventalina colonies survived and variations in growth were comparable to the mean, $2.6 \pm 1.9 \mathrm{~cm}$ (expressed as $95 \% \mathrm{CI}$ ), over a $230 \mathrm{~d}$ period in Panama (Birkeland 1974). Unfortunately however, detailed comparisons among gorgonians are largely precluded because such studies were conducted over short $(\leq 1 \mathrm{yr}$ ) periods in widely scattered locales and limited to single (or a few) species.

The combination of low mortality and large shortterm variability in growth indicates that the statistical detection of species-specific differences, if any, would be difficult. These difficulties are potentially alleviated by long-term observations. Differences in survival should become more apparent with time and variations in growth may be reduced if such variations represent an 'artifact' of short-term measurements. In addition, observations of several species at a given site would reduce variability caused by site-specific effects.

In this report we examine colony survival and growth rates for several shallow-water gorgonian species over a 4.5 yr period, from early winter 1983 to late spring 1988 , at 2 sites on the southwest coast of Puerto Rico. We also attempt to identify sources of colony mortality and factors responsible for variations in growth rates. We then interpret these results in terms of ecological differentiation among shallow-water gorgonians of the Caribbean.

\section{STUDY SITES AND METHODS}

Growth and survival of gorgonian colonies were studied at 2 sites near La Parguera on the southwest coast of Puerto Rico. One site $\left(17^{\circ} 56.2^{\prime} \mathrm{N}, 67^{\circ} 3.2^{\prime} \mathrm{W}\right)$ is located about $0.5 \mathrm{~km}$ offshore of Media Luna reef (henceforth called Media Luna) and has low relief at a depth of $6.7 \mathrm{~m}$. The other site $\left(17^{\circ} 55.7^{\prime} \mathrm{N}, 67^{\circ} 4.4^{\prime} \mathrm{W}\right)$ is located about $1 \mathrm{~km}$ offshore of San Cristobal reef (henceforth San Cristobal) and has moderate topographic relief at a depth of $10.6 \mathrm{~m}$. Both sites are fully exposed to wave action generated by the easterly tradewinds, although surge is noticeably more evident at Media Luna due to its shallower depth. The sessile fauna is visually dominated by gorgonians at both sites. 
Percent cover by scleractinian corals and other sessile fauna is about 8 and $25 \%$ at Media Luna and San Cristobal respectively ( $V$. Vicente pers. comm.).

Gorgonian colonies were monitored in a $1 \times 32 \mathrm{~m}$ transect at both sites from early winter 1983 to late spring 1988. Colony survival and heights (measured to the nearest $\mathrm{cm}$ ) were usually monitored at 6 mo intervals. Individual colonies were located by placing a $0.5 \mathrm{~m}^{2}(0.5 \times 1.0 \mathrm{~m})$ quadrat subdivided into $1 / 16 \mathrm{~m}^{2}$ $(25 \times 25 \mathrm{~cm})$ areas along the transect. A chain and nails placed at $0.5 \mathrm{~m}$ intervals in the center and along the edges of the transect were used to reposition quadrats between surveys.

Gorgonians were identified by field characteristics, although identifications of large colonies $(\geq 25 \mathrm{~cm}$ in height) were verified by spicule preparations (following Bayer 1961) from branch tip samples. Unfortunately, several individuals could not be identified to species level because of small colony size or variations in spicule and field characteristics. However, these difficulties do not unduly affect the results because the number of colonies involved was relatively small $(\leq 15 \%)$.

In addition to recording the height and survival of colonies, we noted possible causal factors. These included weakening of the substratum, loosening of the holdfast, tissue damage arising from various biological or physical sources, the presence of predators, and overgrowth by other organisms.

\section{DATA ANALYSIS}

We used the Kolmogorov-Smirnov 2-sample test (rather than tests of central tendency) to detect sizespecific patterns of mortality because both smaller and larger colonies may experience higher mortalities (Birkeland 1974). Other aspects of colony mortality

Table 1. Numbers and sizes (heights in $\mathrm{cm}$ ) of colonies which died or survived at San Cristobal and Media Luna. Sizes are for fall 1983. n: no. of colonies; $\bar{x}$ : mean; (SD): Standard Deviation; Med: Median; (W): range; \%S: \% survival over the entire 4.5 yr study period $\% \mathrm{~S} \mathrm{yr}^{-1}: \%$ survival on an annual basis. Annual survival was calculated on initial and final colony numbers assuming a constant mortality rate

\begin{tabular}{|c|c|c|c|c|c|c|c|c|c|c|c|c|}
\hline \multirow[t]{2}{*}{ Species } & \multicolumn{5}{|c|}{ Live } & \multicolumn{5}{|c|}{ Dead } & \multirow[t]{2}{*}{$\% \mathrm{~S}$} & \multirow{2}{*}{$\begin{array}{l}\% \mathrm{~S} \\
\mathrm{yr}^{-1}\end{array}$} \\
\hline & $\mathrm{n}$ & $\overline{\mathrm{x}}$ & $(\mathrm{SD})$ & Med & $(W)$ & $\mathrm{n}$ & $\bar{x}$ & (SD) & Med & $(\mathrm{W})$ & & \\
\hline \multicolumn{13}{|l|}{ Media Luna } \\
\hline Pseudopterogorgia americana & 21 & 23.5 & $(21.6)$ & 18.0 & $(1-94)$ & 14 & 33.4 & $(23.1)$ & 30.5 & $(1-86)$ & 60.0 & 89.3 \\
\hline P. acerosa & 12 & 69.6 & $(41.3)$ & 59.0 & $(12-140)$ & 4 & 49.3 & $\{29.8\}$ & 61.0 & $(5-79)$ & 75.0 & 93.8 \\
\hline Plexaura flexuosa & 14 & 28.8 & (18.9) & 24.5 & $(2-59)$ & 12 & 39.5 & (25.5) & 44.0 & $(1-68)$ & 53.8 & 87.1 \\
\hline Pseudoplexaura wagenaani & 30 & 21.4 & $(10.5)$ & 24.3 & $(1-42)$ & 15 & 12.2 & $(11.7)$ & 10.0 & $(1-36)$ & 66.7 & 91.4 \\
\hline P. porosa & 14 & 22.1 & $(7.4)$ & 20.8 & $(1-31)$ & 9 & 17.3 & $(9.3)$ & 18.0 & $(1-32)$ & 60.9 & 89.6 \\
\hline Gorgonia ventalina & 22 & 33.7 & $(20.8)$ & 37.0 & $(1-68)$ & 6 & 6.9 & $(4.6)$ & 7.0 & $(2-15)$ & 78.6 & 94.8 \\
\hline Subtotal & 113 & & & & & 61 & & & & & 64.9 & 90.9 \\
\hline Other species & 62 & & & & & 24 & & & & & 72.1 & 93.0 \\
\hline GRAND TOTAL & 175 & & & & & 85 & & & & & 67.3 & 91.6 \\
\hline \multicolumn{13}{|l|}{ San Cristobal } \\
\hline Pseudopterogorgia americana & 77 & 23.3 & $(17.5)$ & 21.0 & $(1-81)$ & 25 & 32.6 & $(31.4)$ & 19.0 & $(2-110)$ & 75.4 & 93.9 \\
\hline P. acerosa & 24 & 36.8 & $(27.6)$ & 31.5 & $(3-110)$ & 9 & 27.7 & $(28.8)$ & 15.0 & $(2-75)$ & 72.7 & 93.2 \\
\hline Plexaura flexuosa & 44 & 22.7 & $(18.8)$ & 18.5 & $(1-77)$ & 20 & 15.8 & $(14.5)$ & 13.5 & $(1-52)$ & 68.8 & 92.0 \\
\hline P. homomalla & 19 & 18.3 & $(10.9)$ & 20.0 & $(1-40)$ & 12 & 16.4 & $(9.8)$ & 12.2 & $(4-32)$ & 61.3 & 89.7 \\
\hline P. homomalla f. kukenthalli & 22 & 11.9 & (6.1) & 11.8 & $(3-29)$ & 15 & 9.8 & $(6.8)$ & 7.5 & $(2-27)$ & 59.5 & 89.1 \\
\hline Pseudoplexaura wagenaan & 39 & 29.2 & $(11.7)$ & 27.0 & $(8-58)$ & 8 & 22.7 & $(19.7)$ & 16.0 & $(6-61)$ & 83.0 & 95.9 \\
\hline P. porosa & 28 & 26.8 & $(10.3)$ & 28.3 & $(10-51)$ & 11 & 27.3 & $(12.6)$ & 27.0 & $(7-67)$ & 71.8 & 92.9 \\
\hline Eunicea tourneforti & 22 & 22.0 & $(15.8)$ & 19.8 & $(1-72)$ & 7 & 17.3 & $(13.8)$ & 14.5 & $(4-36)$ & 75.9 & 94.0 \\
\hline E. laxispica & 16 & 12.6 & $(8.0)$ & 11.0 & $(2-25)$ & 10 & 12.6 & $(10.5)$ & 7.0 & $(1-32)$ & 61.5 & 89.8 \\
\hline E. succinea & 14 & 17.4 & $(9.6)$ & 20.0 & $(3-21)$ & 3 & 22.0 & $(7.6)$ & 21.0 & $(15-30)$ & 82.4 & 95.8 \\
\hline Gorgonia ventalina & 37 & 24.0 & $(21.6)$ & 18.8 & $(1-102)$ & 16 & 17.6 & (19.3) & 18.5 & $(1-50)$ & 69.8 & 92.3 \\
\hline Muriceopsis flavida & 21 & 15.5 & $(12.8)$ & 13.0 & $(1-38)$ & 9 & 16.4 & (14.4) & 12.5 & $(3-38)$ & 70.0 & 92.4 \\
\hline Plexaurella dichotoma & 18 & 41.5 & $(25.2)$ & 46.0 & $(4-104)$ & 3 & 24.0 & $(22.5)$ & 25.0 & $(1-46)$ & 85.7 & 96.6 \\
\hline Subtotal & 381 & & & & & 148 & & & & & 72.7 & 93.0 \\
\hline Other species & 112 & & & & & 62 & & & & & 64.4 & 90.7 \\
\hline GRAND TOTAL & 493 & & & & & 210 & & & & & 70.1 & 92.4 \\
\hline
\end{tabular}


were analyzed by tests of frequencies ( $G$-test; Sokal \& Rohlf 1981), and consequently restricted to instances when $\geq 80 \%$ of expected values were $\geq 5$.

Analyses of growth rates were limited to colonies which survived through the entire study period because of our desire to obtain long-term estimates of growth. Growth estimates were based on the initial (early winter 1983) and final (late spring 1988) measurements of colony heights. Also, to ensure that estimates of variability in growth rates were not unduly affected by small sample size, analyses were restricted to species where $>10$ colonies survived at a site. All measurements, including instances of negative growth, were used in these analyses. As a consequence it should be noted that the resultant estimates represent the net rather than 'optimal' growth rates. Normality and equality of variances in growth rates were examined with the Kolmogorov-Smirnov 1-sample test and the F-test respectively, prior to analyses of differences in growth rates among species. The 0.05 level was used as the criterion for statistical significance.

\section{RESULTS}

\section{Colony mortality rates}

We compared the heights of colonies that survived or died during the study period by using the initial measurements of early winter 1983 (Table 1). No significant differences were observed for any taxa at either site (Kolmogorov-Smirnov 2-sample test). [This result is

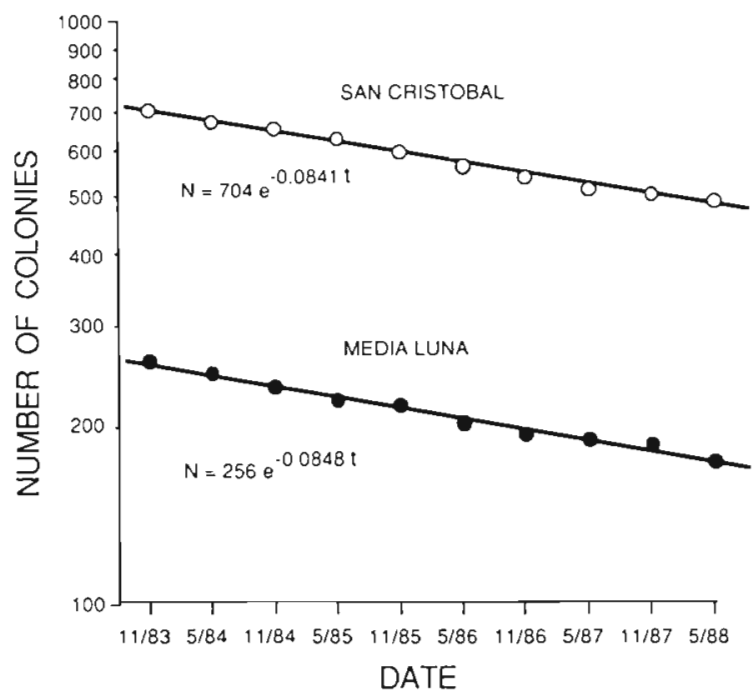

Fig. 1. Semi-logarithmic plot of gorgonian colony survival at the Media Luna and San Cristobal study sites. N: number of colonies; t: time (yr) after early winter 1983 partially attributable to the relatively low abundances of small ( $\leq 5 \mathrm{~cm}$ ) colonies; see 'Discussion']. As a consequence, colony size was not considered in comparisons of mortalities among species.

Colony survivals over the study period for individual species ranged from $59.5 \%$ (Plexaura homomalla $\mathrm{f}$. kukenthalli) to $85.7 \%$ (Plexaurella dichotoma) at San Cristobal and from $53.8 \%$ (Plexaura flexuosa) to $78.6 \%$ (Gorgonia ventalina) at Media Luna (Table 1). Differences in colony survivals among species were not significantly different at San Cristobal $(\mathrm{p}>0.10, G=$ 13.37, $\mathrm{df}=12)$ and Media Luna $(\mathrm{p}>0.10, G=5.16, \mathrm{df}$ $=5$ ). In addition, no significant differences in colony survival were observed between sites for any species (G-test).

Based on pooled data, 70.1\% (493/703) and 67.3\% $(175 / 260)$ of the colonies survived over the entire study period at San Cristobal and Media Luna respectively. A semi-log plot of overall colony survivorship (Fig. 1) is apparently linear (i.e. exponential) indicating that the probability of survival was constant during the study period. The slopes of Model I linear regressions were equivalent to colony survivals of 91.93 and $91.87 \% \mathrm{yr}^{-1}$ at San Cristobal and Media Luna respectively.

\section{Sources of colony mortality}

Inferred sources of colony mortality are given in Table 2. We distinguished 3 major categories of colony mortality: (1) detachment, (2) basal fracture, and (3) competitive overgrowth.

Table 2. Sources of colony mortality

\begin{tabular}{|lrrrr|} 
& \multicolumn{3}{c}{ Media } & \multicolumn{3}{c}{ Luna } & \multicolumn{2}{c}{ Sanstobal } \\
& No. & $\%$ & No. & $\%$ \\
& died & & died & \\
& & & & \\
& & & & \\
Detachment & 2 & 2.3 & 25 & 11.9 \\
Fallen or loosely attached & 32 & 37.6 & 124 & 59.0 \\
Disappeared & 34 & 40.0 & 149 & 70.9 \\
$\quad$ Subtotal & & & & \\
Basal fracture & 9 & 10.6 & 10 & 4.8 \\
Damaged base (abrasion) & 22 & 25.9 & 27 & 12.9 \\
Damaged base (unknown) & 8 & 9.4 & 10 & 4.8 \\
Undamaged base & 39 & 45.9 & 47 & 22.4 \\
$\quad$ Subtotal & & & & \\
Overgrowth & 3 & 3.5 & 3 & 1.4 \\
Millepora & 6 & 7.1 & 3 & 1.4 \\
Algae & 3 & 3.5 & 8 & 3.8 \\
Other & 12 & 14.1 & 14 & 6.7 \\
$\quad$ Subtotal & 85 & 100.0 & 210 & 100.0 \\
$\quad$ Total & & & & \\
\hline
\end{tabular}


Detachment was the major source of mortality at San Cristobal and Media Luna (70.9 and 40.0\% respectively). We assumed that the disappearance of entire colonies was due to detachment. In some cases we noted circumstantial evidence for detachment involving preceding observations of partial detachment, or the presence of substrate 'scars' after the disappearance of colonies.

Basal fracture, defined as the breakage of the axial skeleton near the colony base, accounted for 45.9 and $22.4 \%$ of the mortalities at Media Luna and San Cristobal respectively. About $79 \%$ of the colonies suffering fracture at Media Luna (31/39) and San Cristobal (37/ 47) were observed to be damaged at the base prior to mortality (Table 2), indicating that injury to basal tissue increases the probability that a colony will eventually experience basal fracture. Comparisons of mortalities between colonies with damaged and undamaged bases confirms this relationship. Significantly higher mortalities were found for colonies with damaged compared to undamaged bases at Media Luna (89 vs $20 \%$, $\mathrm{p}<0.001, G=52.63, \mathrm{df}=1$ ) and San Cristobal (62 vs $30 \%, \mathrm{p}<0.001, G=20.54, \mathrm{df}=1$ ). Our field observations indicate that physical abrasion (presumably by rocks or other objects) is the predominant cause of basal damage. [The cause of basal damage could not be determined in most instances because colony bases were already damaged at the beginning of the study (i.e. the 'unknown' category in Table 2).]

Competitive overgrowth accounted for only 14.1 and $6.7 \%$ of mortalities at Media Luna and San Cristobal respectively. The principal organisms overgrowing gorgonians were the fire coral Millepora and the sponges Desmopsamma anchorata and Haliclona viridis. Our overgrowth category also included instances where only the bare axial skeleton (except for a thin filamentous algal film) remained following mortality. Disease (Feingold 1988), rather than overgrowth, may have been responsible in such cases.

It should be emphasized that the above classification of mortalities is somewhat oversimplified because sources of mortality may not be mutually exclusive. For instance, overgrowth by other organisms on previously-damaged colony bases may play a contributing role in basal fractures. It is also interesting to note that predation played a negligible role in colony mortalities (but see 'Discussion'). This result was somewhat surprising because gorgonian predators (principally the mollusc Cyphoma gibbosum and the fireworm Hermodice carunculata) or evidence of their activity were noted frequently during this study.

Mortalities by detachment, basal fracture and overgrowth differed significantly between sites $(\mathrm{p}<0.001$, $G=24.21, \mathrm{df}=2$ ). We attribute the higher frequency of

Table 3. Mean growth rates ( $\mathrm{cm} \mathrm{yr}^{-1}$ ) in colony heights of gorgonians at Media Luna (ML) and San Cristobal (SC). (SD): Standard Deviation; CV: Coefficient of Variation $(100 \mathrm{~S} / \overline{\mathrm{X}})$; Med: Median; $\mathrm{n}$ : number of colonies

\begin{tabular}{|c|c|c|c|c|c|c|}
\hline Species & Site & $\bar{X}$ & $(\mathrm{SD})$ & $\mathrm{CV}$ & Med & $n$ \\
\hline Pseudopterogorgia americana & $\begin{array}{l}\text { ML } \\
\text { SC }\end{array}$ & $\begin{array}{l}3.44 \\
4.48\end{array}$ & $\begin{array}{l}(3.12) \\
(2.82)\end{array}$ & $\begin{array}{l}90.7 \\
62.9\end{array}$ & $\begin{array}{l}2.88 \\
4.00\end{array}$ & $\begin{array}{l}21 \\
77\end{array}$ \\
\hline P. acerosa & $\begin{array}{l}\mathrm{ML} \\
\mathrm{SC}\end{array}$ & $\begin{array}{l}2.12 \\
4.03\end{array}$ & $\begin{array}{l}(3.03) \\
(3.14)\end{array}$ & $\begin{array}{r}142.9 \\
77.9\end{array}$ & $\begin{array}{l}2.01 \\
2.83\end{array}$ & $\begin{array}{l}12 \\
24\end{array}$ \\
\hline Pseudoplexaura wagenaari & $\begin{array}{l}\text { ML } \\
\text { SC }\end{array}$ & $\begin{array}{l}2.57 \\
2.13\end{array}$ & $\begin{array}{l}(1.88) \\
(2.16)\end{array}$ & $\begin{array}{r}73.2 \\
101.4\end{array}$ & $\begin{array}{l}2.81 \\
2.59\end{array}$ & $\begin{array}{l}30 \\
39\end{array}$ \\
\hline Gorgonia ventalina & $\begin{array}{l}\mathrm{ML} \\
\mathrm{SC}\end{array}$ & $\begin{array}{l}1.92 \\
2.34\end{array}$ & $\begin{array}{l}(2.02) \\
(2.52)\end{array}$ & $\begin{array}{l}105.2 \\
107.2\end{array}$ & $\begin{array}{l}1.76 \\
2.59\end{array}$ & $\begin{array}{l}22 \\
37\end{array}$ \\
\hline Pseudoplexaura porosa & $\begin{array}{l}M L \\
S C\end{array}$ & $\begin{array}{l}1.98 \\
2.22\end{array}$ & $\begin{array}{l}(1.52) \\
(1.96)\end{array}$ & $\begin{array}{l}76.8 \\
88.3\end{array}$ & $\begin{array}{l}2.35 \\
2.13\end{array}$ & $\begin{array}{l}14 \\
28\end{array}$ \\
\hline Eunicea laxispica & $\mathrm{SC}$ & 2.21 & $(1.68)$ & 76.0 & 2.11 & 16 \\
\hline Plexaura llexuosa & $\begin{array}{l}\text { ML } \\
S C\end{array}$ & $\begin{array}{l}2.15 \\
1.77\end{array}$ & $\begin{array}{l}(1.27) \\
(1.68)\end{array}$ & $\begin{array}{l}59.1 \\
94.9\end{array}$ & $\begin{array}{l}1.42 \\
2.00\end{array}$ & $\begin{array}{l}14 \\
44\end{array}$ \\
\hline Eunicea tourneforti & $\mathrm{SC}$ & 2.06 & $(1.71)$ & 83.0 & 2.00 & 22 \\
\hline Plexaura homomalla & $\mathrm{SC}$ & 1.99 & $(1.29)$ & 64.8 & 1.88 & 19 \\
\hline Muriceopsis flavida & $\mathrm{SC}$ & 1.85 & $(1.61)$ & 87.0 & 1.41 & 21 \\
\hline Euricea succinea & $\mathrm{SC}$ & 1.36 & $(1.86)$ & 136.8 & 1.41 & 14 \\
\hline P. homomalla f. kukenthalli & $\mathrm{SC}$ & 1.18 & $(1.10)$ & 93.2 & 1.18 & 22 \\
\hline Plexaurella dichotoma & $\mathrm{SC}$ & 0.80 & $(1.94)$ & 242.5 & 0.95 & 18 \\
\hline
\end{tabular}


detachment at San Cristobal (70.9 vs $40.0 \%$ ) to a 'softer' substrate (based on our experience in pounding nails into the bottom). Several factors indicate that the higher incidence of basal fracture at Media Luna $(45.9$ vs $22.4 \%$ ) reflects greater wave action. Colonies at Media Luna had significantly higher incidences of suffering (1) basal damage $(16.9 \%$ or $44 / 260$ vs $10.8 \%$ or $76 / 703$ at San Cristobal; $\mathrm{p}<0.05, G=6.0$, df $=1$ ), as well as (2) basal fracture following such damage $(89 \%$ or $39 / 44$ vs $62 \%$ or $47 / 76$ respectively; $p<0.005, G=$ 9.34, df $=1$ ).

Unfortunately, sample sizes were too small to determine if the 3 major sources of mortality differed among species at each study site.

\section{Colony growth rates}

Although Pseudopterogorgia americana and a few other species displayed a tendency for growth rates to decrease with colony size, such relationships were statistically nonsignificant in all cases (regression analysis) Consequently, colony size was not employed as a covariable in comparisons of growth rates among species.

Characteristics of colony growth rates of the more abundant species are shown in Table 3. Mean growth rates of most species were between 1.4 and $2.6 \mathrm{~cm} \mathrm{yr}^{-1}$,

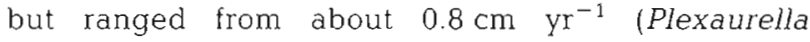
dichotoma) to $4.5 \mathrm{~cm} \mathrm{yr}^{-1}$ (Pseudopterogorgia americana). Intraspecific variability in growth was high for all species; coefficients of variation $(\mathrm{CV})$ ranged from about 60 to $240 \%$ among species, indicating that variability in growth is roughly equivalent to average growth increments. These results indicate that the large variations in growth reported in previous studies are not an 'artifact' of short-term observations because differences among colonies are not 'averaged out' over longer time intervals. This feature is demonstrated in

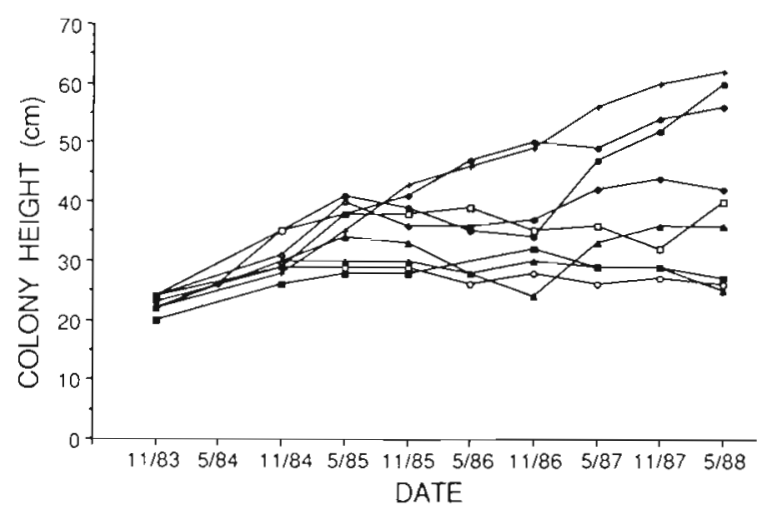

Fig. 2. Pseudopterogorgia americana. Growth of colonies which were between 20 to $24 \mathrm{~cm}$ tall in early winter 1983 at the San Cristobal site
Table 4. A posteriori tests for significant differences in growth rates at San Cristobal. Species displaying no significant differences are connected by underlines. Species codes: Pam, Pseudopterogorgia americana; Pac, P. acerosa; Pwg, Pseudoplexaura wagenaari Gv, Gorgonia ventalina; Ppr Pseudoplexaura porosa; Elx, Eunicea laxispica: Et, E toumeforti; Pfx, Plexaura flexuosa; Ph, P. homomalla; Mfv, Muriceopsis flavida: Esc, Eunicea succinea; Phk, $P$. homomalla f. kukenthalli; Pdh, Plexaurella dichotoma

Pam Pac Pwg Gv Ppr Elx Et Pfx Ph Mfv Esc Phk Pdh

Fig. 2 which shows the growth of $P$. americana colonies at San Cristobal whose heights ranged from 20 to 24 and from 25 to $62 \mathrm{~cm}$ at the beginning and end of the study period respectively.

Although growth increments were generally not statistically different from a normal distribution (Kolmogorov-Smirnov 1-sample test), a significant difference in variances precluded analyses by parametric ANOVA procedures. As a consequence, the KruskalWallis-Test was used to compare growth rates among species. Growth rates were different among species at San Cristobal ( $p<0.005, \chi_{12}^{2}=82.9$ ) but not at Media Luna $\left(p>0.10, \chi_{5}^{2}=8.02\right)$. A posteriori tests (Hollander $\&$ Wolfe 1973) indicated nonsignificant differences in 69 of 78 comparisons between species pairs at San Cristobal, and that the source of significance is primarily due to the higher growth rates of Pseudopterogorgia americana (Table 4).

To determine if growth may be influenced by sublethal effects, the growth of uninjured colonies were compared to colonies known to be injured by predators, overgrowth, abrasion and other factors during the study (Table 5). (We deleted a few cases where injuries involved breaking of the tallest branch since negative growth would necessarily result in this circumstance.) Uninjured colonies grew faster than injured colonies in all 17 cases where comparisons were possible. However, only 6 within-case comparisons were significant ( $t$-test) indicating that such differences in growth rates were relatively small in most instances. Expressed alternatively, these results indicate that sublethal injuries are partly responsible for intraspecific variations in growth, but that the 'variability explained' may be relatively small in many cases.

\section{DISCUSSION}

\section{Colony mortality}

Annual survival rates of colonies at Media Luna and San Cristobal were essentially equivalent (about $92 \%$ ), 
Table 5. Growth rates ( $\mathrm{cm} \mathrm{yr}^{-1}$ ) of injured and uninjured colonies. ML: Media Luna; SC: San Cristobal; n: number of colonies; (SD): Standard Deviation. Probabilities based on $t$-test

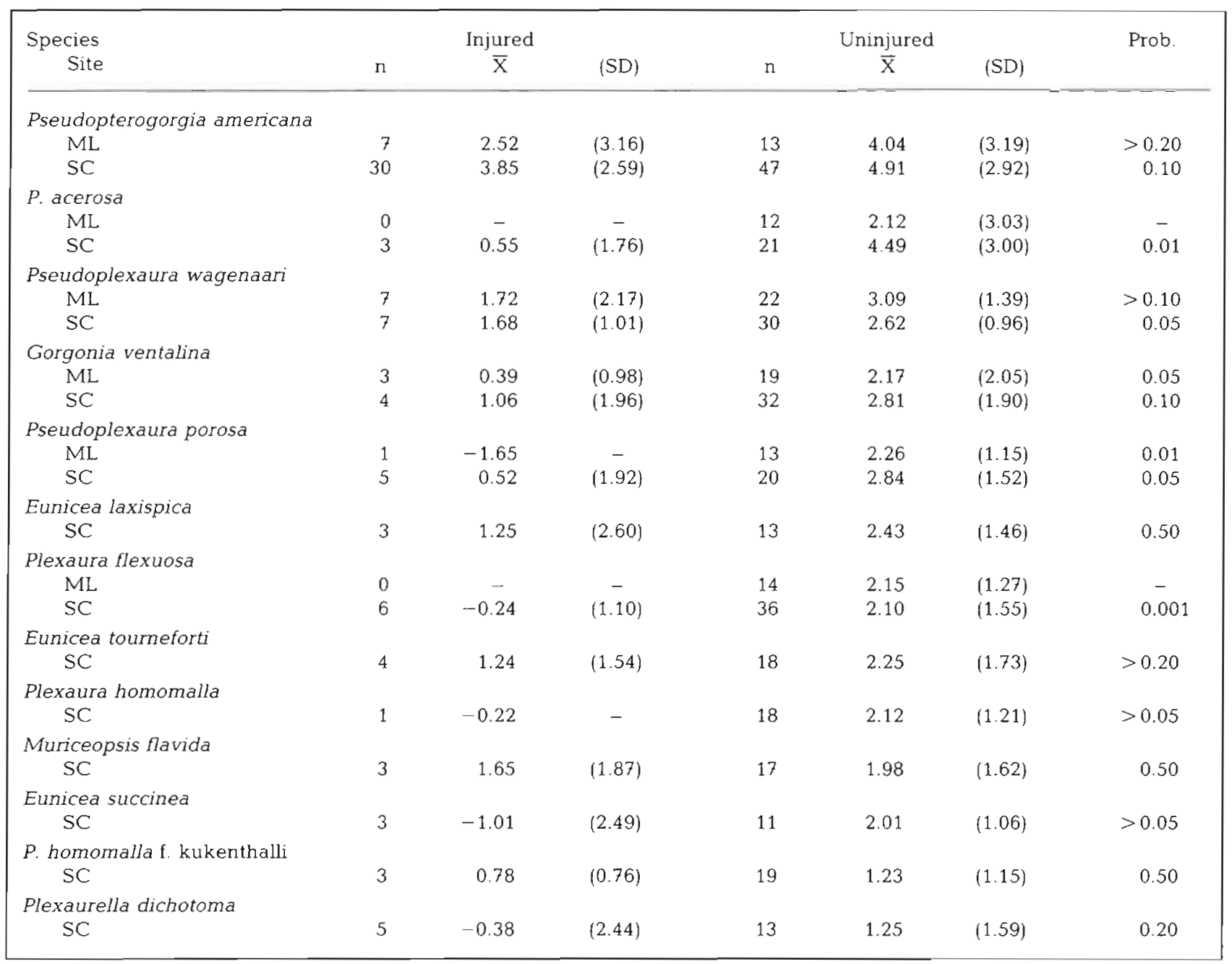

and in remarkable agreement with the $92.4 \%$ value (recalculated on an annual basis) observed by Birkeland (1974) for Gorgonia ventalina in Panama. However, significant differences in the sources of mortality between Media Luna and San Cristobal suggest that these similarities may be partly coincidental. Wahle (1985) has previously concluded that the rates and sources of colony mortality vary spatially.

An important result of this study was the lack of significant differences in mortalities among species. We recognize that the failure to detect statistical significance is dependent upon sample sizes and duration of the study period. For example, assuming that the observed differences in mortalities among species represent 'true differences', statistically significant results would be achieved at San Cristobal if sample sizes were doubled (to more than 1000 colonies) or if the study period was tripled (to $13.5 \mathrm{yr}$ ). However, we believe that the observed differences in mortalities represent random sampling variability because several considerations indicate that the dominant causes of colony mortality - detachment and basal fracture - are largely nonselective among species. We concur with the contention of Cary (1914), Kinzie (1973) and Birkeland (1974) that colony detachment generally results from the failure of the underlying substrate rather than the colony holdfast itself. Because settling planula are probably unable to detect differences in substrate integrity (Wahle 1985) there is little reason to infer a strong species-specific component in colony detachment. In an analogous terrestial situation with trees, Vogel (1988) has argued that unfavorable properties of the substrate cannot be countered directly by natural selection. 
A similar argument can be made for basal fracture. This study demonstrates that damage to basal tissues usually precedes fracture. The major source of such damage is probably abrasion by rocks or other objects (see also Cary 1914) which, in turn, is presumably nonselective among species. With respect to basal damage, it is interesting to note that the predator Cyphoma gibbosum, although displaying prey preferences (Lasker \& Coffroth 1988), generally avoids the basal regions of colonies (Harvell \& Suchanek 1987).

\section{Colony growth}

Growth rates measured in this study are generally comparable to values reported from other locales, indicating that these results are representative of shallowwater gorgonians of the Caribbean. For instance, Kinzie (1974) found that Plexaura homomalla grows $2.0 \mathrm{~cm}$ $\mathrm{yr}^{-1}$ in the Grand Caymans compared to $1.99 \mathrm{~cm} \mathrm{yr}^{-1}$ in this study. Alternatively, the higher rates for Gorgonia ventalina in Panama reported by Birkeland (1974) $\left(4.1 \mathrm{~cm} \mathrm{yr}^{-1}\right.$ compared to about $2.1 \mathrm{~cm} \mathrm{yr}^{-1}$ in this study) may partially reflect our inclusion of zero and negative growth increments. Major differences in colony morphology probably underlie the relatively few cases where growth differed significantly between species. The fastest-growing species, Pseudopterogorgia americana (and possibly $P$, acerosa), which grows about $4 \mathrm{~cm} \mathrm{yr}^{-1}$, is characterized by thin branch tips; while the slowest-growing taxa, Plexaurella dichotoma $\left(0.8 \mathrm{~cm} \mathrm{yr}^{-1}\right)$, has the thickest branches of the gorgonians examined. The remaining species generally have branches of intermediate thicknesses. This pattern suggests a tradeoff between the elongation and thickening of branches. The only exception to this relationship is the thin-branched $G$. ventalina. However, the anastomosing branch structure of this species is unique among the gorgonians examined.

An important result of this study is that intraspecific variations in growth are large, even over long (multiyear) time scales. Extrinsic factors such as injuries are evidently responsible for some of the variations in growth among colonies. The high variability in growth rates implies that height is a poor indicator of colony age. For instance, with a variation of $\pm 1 \mathrm{SD}$, a $100 \mathrm{~cm}$ tall Pseudopterogorgia americana at San Cristobal could be between 14 and 60 yr old (mean estimate: 22 yr). On a more theoretical level, this result suggests that the demography of gorgonians may be more appropriately approached from a size-rather than agerelated basis (e.g. Caswell 1989), especially if characteristics such as the age of sexual maturity and reproductive output are more highly related to colony size rather than age (Wahle 1983).

\section{Conclusions and caveats}

In conclusion, we find no overwhelming reason to reject the null hypotheses of no differences in mortality or growth rates among gorgonian species. Although significant differences in growth rates were detected, such differences involved only a few of the species examined. Conversely however, we do not imply that species-specific differences are nonexistent, but rather that such differences are relatively small and largely obscured by 'random' extrinsic factors.

The similarities in mortality and growth rates among species may be related to the colonial (modular) structure of gorgonians. For instance, although the presence of chemical and structural defenses (Harvell \& Suchanek 1987, Harvell et al. 1988) suggests that predation has played a major role in the evolutionary history of gorgonians, the effects of predation are essentially limited to mortalities of individual zooids rather than the colony as a whole. One consequence of the colonial habit is that the sublethal effects of predation (and other factors) contribute to increased variability in colony growth rates, thereby obscuring speciesspecific differences of growth. Sources of colony mortality that remain are associated with the holdfast and base, areas of the colony for which the modular structure offers little advantage. Jackson (1977) has previously discussed various ecological consequences of colonial growth.

The results and conclusions of this study are based on several constraints which merit comment. The study period is probably representative of normal 'background' conditions at exposed locations between episodes of severe storm activity (but see Yoshioka \& Yoshioka 1987 for the effects of Hurricane David). More importantly, it must be emphasized that the results are probably representative of a typical, 'mature' assemblage of gorgonians in which the majority of colonies are relatively large. (More than $85 \%$ of the colonies at both sites were $>5 \mathrm{~cm}$ tall at the beginning of this study.) A parallel examination of colonies which recruited (ca $1 \mathrm{~cm}$ tall) during the study period reveals well-developed differences in growth and mortality rates among species (Yoshioka \& Yoshioka unpubl.). Several factors are evidently responsible for the dependence of species-specific patterns on colony size. Predation, competitive overgrowth and factors such as burial (Gotelli 1988) are more likely to cause mortality in small colonies. Differential susceptibilities to such effects would result in species-specific patterns of mortalities for small (but not large) colonies. Similarly, the mortality of small colonies affected by such factors eliminates a source of variability in growth, thereby making species-specific differences in growth rates more pronounced statistically. Following the con- 
ceptual theme discussed above, the relative absence of species-specific patterns of mortality and growth rates in larger gorgonians may be related to the fact than the ecological consequences of modular growth increase with colony size.

\section{LITERATURE CITED}

Bayer, F. M. (1961). The shallow-water octocorallia of the West Indian region. Martinus Nijhoff, The Hague

Birkeland, C. (1974). The effect of wave action on the population dynamics of Gorgonia ventalina Linnaeus. Stud. trop. Oceanogr 12: 115-126

Cary, L. R. (1914). Observations upon the growth-rate and oecology of gorgonians. Publ. Carnegie Inst. Wash. 182: $79-90$

Caswell, H. (1989). Matrix population models. Sinauer Assoc., Sunderland

ConnelI, J. H. (1978). Diversity in tropical rain forests and coral reefs. Science 199: 1302-1309

Feingold, J. S. (1988). Ecological studies of a cyanobacterial infection on the Caribbean sea plume Pseudopterogorgia acerosa (Coelenterata: Octocorallia). Proc. 6th Inti. Coral Reef Symp., Australia 3: 157-162

Gotelli, N. J. (1988). Determinants of recruitment, juvenile growth, and spatial distribution of a shallow-water gorgonian. Ecology 69: 157-166

Harvell, C. D., Fenical, W., Greene, C. H. (1988). Chemical and structural defenses of Caribbean gorgonians (Pseudopterogorgia spp.). I. Development of an in situ feeding assay. Mar. Ecol. Prog. Ser. 49: 287-294

This article was submitted to the editor
Harvell, C. D., Suchanek, T H. (1987). Partial predation on tropical gorgonians by Cyphoma gibbosum (Gastropoda). Mar. Ecol. Prog. Ser. 38: 37-44

Hollander, M., Wolfe, D. A. (1973). Nonparametric statistical methods. John Wiley and Sons, New York

Jackson, J. B. C. (1977). Competition on marine hard substrata: the adaptive significance of solitary and colonial strategies. Am. Nat. 111. 743-767

Kinzie, R. A. III. (1973). The zonation of West Indian gorgonians, Bull. mar. Sci. 23: 93-155

Kinzie, R. A. IIl. (1974). Plexaura homomalla: the biology and ecology of a harvestable resource. Stud. trop. Oceanogr. 12: $22-38$

Lasker, H. R., Coffroth, M. A. (1988). Temporal and spatial stability among grazers: variability in the distribution of the gastropod Cyphoma gibbosum on octocorals. Mar Ecol. Prog. Ser. 43: 285-295

Sokal, R. R., Rohlf, F. J. (1981). Biometry. W. H. Freeman, San Francisco

Vogel, S. (1988). Life's devices. Princeton Univ. Press, Princeton

Wahle, C. M. (1983). The roles of age, size and injury in sexual reproduction among Jamaican gorgonians. Am. Zool. 132: 961

Wahle, C. M. (1985). Habitat-related patterns of injury and mortality among Jamaican gorgonians. Bull. mar. Sci. 37 : 905-927

Yoshioka, B. B. (1979). Aspects of the ecology of Pseudopterogorgia americana and Pseudopterogorgia acerosa. M. S. thesis. Univ. Puerto Rico, Mayaguez

Yoshioka, P. M., Yoshioka, B. B. (1987). Variable effects of Hurricane David on the shallow-water gorgonians of Puerto Rico. Bull. mar. Sci. 40: 132-144

Manuscript first received: March 23, 1990

Revised version accepted: October 24, 1990 